\title{
Editorial
}

\section{The Financial and Economic Attributes of Insurers}

\author{
Etti G. Baranoff \\ Virginia Commonwealth University, Snead Hall, 301 West Main Street, Richmond, VA 23284, U.S.A. \\ E-mail: ebaranof@vcu.edu
}

The Geneva Papers (2012) 37, 401-404. doi:10.1057/gpp.2012.28

Since the beginning of the global financial crisis in 2008, the Insurance and Finance (IF) Programme of The Geneva Association has pursued a research agenda providing a lot of input to policymakers in the area of financial stability in insurance (FSI). The need to explain the special attributes of the insurance model as differentiated from that of the banking model was initiated by the call of the Group of Twenty (G-20) Finance Ministers and Central Bank Governors to create stability in the financial markets including the insurance sector. The G-20 asked the Financial Stability Board (FSB) to develop methodologies to identify financial institutions that: (i) can cause impairment to all or parts of the financial system; and (ii) have potentially serious negative consequences for the real economy. The FSB asked the International Association of Insurance Supervisors (IAIS) to help as the international body with expertise in insurance.

The Geneva Association has been heavily involved in shaping the dialogue around financial stability with the main goal of clarifying the particularity of insurance and its unique business model. The efforts have integrated expertise within the industry and the wide academic body of knowledge in the area of "Insurance and Finance". This special issue of The Geneva Papers on Risk and Insurance-Issues and Practice is linked to the IF Programme of The Geneva Association and makes a direct contribution to the overall efforts of the IF Research Programme. The Programme has taken an active role in producing studies in the area of financial stability of the industry. The most noted study is the highly acclaimed "Systemic Risk in Insurance". This report was followed by numerous studies that, together with the large body of insurance solvency, risk management and capital structure research, have contributed to the IAIS decision to regard traditional insurance activities as not systemically risky.

Since the IF Programme of The Geneva Association comprises academic and professional research activities in the fields of finance, this special issue of The Geneva Papers on Risk and Insurance - Issues and Practice is an important layer of added value in the pursuit of understanding the insurance industry and its contribution to economies, stability and growth. This special issue includes eight papers, each focusing on a different topic and methodology that contributes to the body of knowledge for improved insurance regulatory initiatives on the micro and macro levels. The themes

\footnotetext{
${ }^{1}$ The Geneva Association (March 2010).
} 
of the articles illustrate the importance of the insurance sector to economic growth. Insurance products and activities provide signals regarding governance structure of both insurers and other firms, while various other metrics within the insurers' activities provide understanding of capital structure, performance, risk management, reputation, reinsurance and corporate structure.

Zhou et al. feature the overall contribution of the insurance industry to global economic growth of developed and emerging markets. Following previous studies that show stock returns as predictors of financial development, they use insurers' stock returns as a proxy for insurance activities. They examine the link between the role of insurance and economic growth in 23 developed countries and 15 emerging countries, covering a period between 1982 and 2008. Their empirical results show that for the nine groups they created, there is a significantly positive relationship between insurance excess returns and future economic growth. They also add the legal (rules and laws) environment and governance quality indicators by country to link between the role of insurance and economic growth. Their study can also be linked to some of the research of the IF Research Programme of The Geneva Association, namely regarding the role of insurers as long-term investors. The attributes of the industry as investors are important propellers to economic success.

The second article in this special issue moves into the significance of an insurance product, rather than insurers overall. The product is the Directors and Officers (D\&O) liability insurance. Gupta and Prakash construct a panel data set on D\&O insurance purchases by Canadian businesses. They use the insurance limits and premiums as dependent variables signalling governance quality. Using a firm fixed-effects model in simultaneous equations, they find that excess insider control is related negatively to coverage limits. This tells us that the insurance product contains information on the behaviour of insiders with excess control. Their findings illuminate the importance of insurance in signalling information to stakeholders on attributes of managerial behaviour that are hard to observe. Using a measure of "excess control" as a proxy for private information, Gupta and Prakash show that D\&O insurance provides signals not revealed in studies of typical governance characteristics.

While D\&O insurance and its capability to signal firm quality is useful from the investor's perspective, the next article in the issue focuses on the link between insurer behaviour and the actions of its partners in operations. Browne et al. provide evidence of "reserve errors" in relationship to reinsurance and commissions. They test whether insurers who purchase reinsurance or pay contingent commissions report more accurate reserves than other insurers. They cannot find a statistically significant relationship between reinsurance purchases and the size of under-reserving. Since lack of reserve management can destroy relationships with reinsurers and agents and brokers who depend on contingent commissions (even tax authorities and regulators), their finding is important, illustrating the sophistication level of reinsurers. In the debate about insurers as Systemically Important Financial Institutions, reinsurers are often the topic of deliberation. Showing their sophistication and ability to detect risks within the primary insurers is an important contribution to the current topics that are central to The Geneva Association and the work of insurance supervisors.

The reinsurance topic continues with the paper by Lee and Lee. They investigate the relationship between reinsurance decision and insurer's performance. They use panel 
data on a sample of Taiwan property-liability insurers in a two-equation structural model to show the effects of firm performance on reinsurance decisions. The results suggest that performance negatively affects reinsurance, and vice versa. They use a myriad of risk and control variables such as underwriting risks, liquidity ratio, business-line concentration, return on investment, financial holding dummy, firm size and financial leverage. These determinants are commonly used in insurance studies to control for risk effects, especially in capital structure and capital and risk studies such as those of Cummins and Sommer ${ }^{2}$ for the U.S. property-casualty industry, and Baranoff and Sager $^{3}$ for the U.S. life and health insurance industries.

In a drill-down into a more specific risk element, Carter and Power study the reputation risk in the context of the insurance Initial Public Offering process. They show that more reputable underwriters align with less risky larger life insurers. They also show higher returns are required from less reputable insurers. Overall, insurers are rewarded with higher returns for being less risky and using more reputable underwriters than non-insurers. Their paper provides an entry into the topic of capital acquisition and capital structure, which is a central focus in financial research.

Capital is the focal dimension for regulatory surveillance and management controls. It is the topic of Solvency II and the Risk-Based Capital regulation in the United States. In this special issue, the study of D'Arcy and Lwin focuses on the optimal capital structure of international property-liability insurers. They analysed an international data set of 96 insurers from 1992 to 2006 using two measures for firm value (price-to-earnings and market-to-book) and three measures of leverage (liabilities-to-equity, premiums-to-equity and surplus duration). Given their findings and past capital structure research, D'Arcy and Lwin contend that "there is compelling evidence that property-liability insurers should actively manage their capital structure to maximise value". Their results and insights should be valuable to regulators, especially their suggestions that regulators and managers conduct individual insurer's analysis based on the differences across countries.

Connecting to the recent $8^{\text {th }}$ Insurance and Finance Seminar of The Geneva Association in December 2011 is the paper by Gatzert and Wesker, which compares the single European market regulation for financial services, the Solvency II for insurance, and Basel II and the new version of Basel III for banking. During the seminar, executives noted the major problems in calibrating the internal models under Solvency II that are influenced by the financial markets' volatility with the sovereign debt troubles and low interest rates. The CEOs and CFOs noted the "importance of appropriate calibration of regulatory formulas balancing risk and capital to avoid gyrations from volatile markets and interest rates".

In their paper, Gatzert and Wesker emphasise the problems that erupted during the financial crisis with the liquidity risk arising from an asset-liability mismatch in banking. They note that Basel II concentrates on risks on the assets side, while it is important to have stronger emphasis on the relationship between assets and liabilities. This is the approach for insurers with the total balance sheet approach of Solvency II.

\footnotetext{
${ }^{2}$ Cummins and Sommer (1996).

${ }^{3}$ Baranoff and Sager (2011).
} 
They regard the internal model of Solvency II as beneficial, especially "as a truly principles-based regulation is the best way to ensure sufficient flexibility to adopt regulation to the constantly changing business environment". On the negative side, they do point out the disadvantages of the internal model risk due to assumptions that can lead to faulty calibration.

Closing this special issue is the study by Schlütter and Gründl, which "compares the shareholder-value-maximising capital structure and pricing policy of insurance groups against that of stand-alone insurers". Their study wraps up this special Insurance and Finance issue in bringing together the concepts of improving value and performance. Their emphasis is on the added value in creating groups of insurers. They add the dimension of capital allocation and contribute to the area of ring-fencing, a topic of great importance to macro regulators in their attempt to improve financial stability and solutions that could pre-empt the next financial crisis. The area of group regulation is part of the major initiatives of the IAIS. The ComFrame report of the IAIS $^{4}$ shows that the IAIS regards the regulation of groups as a multidisciplinary approach for multilateral use. The paper by Schlütter and Gründl has an added value to the IAIS efforts in this regard.

In conclusion, the readers can see the integration and the interweaving that exist between pure academic research and the efforts undertaken by professional research to sustain beneficial regulatory mechanisms in the era of the financial crisis that is still lingering since 2008. The themes of the eight papers echo areas of the work of the FSI steering committee and the FSI working group of The Geneva Association.

We are very proud to deliver this first special issue of The Geneva Papers on Risk and Insurance-Issues and Practice that is linked to the IF Programme. It reflects the objective of our programme to bring innovative research on accounting, solvency, investments and other aspects of insurance's role in the wider economy. We thank each of the authors for providing us with such quality research that complements the internal working of The Geneva Association so well.

\section{References}

Baranoff, E.G. and Sager, T.W. (2011) 'The interplay between insurers' financial and asset risks during the crisis of 2007-2009', The Geneva Papers on Risk and Insurance - Issues and Practice 36(3): 1-32.

Cummins, J.D. and Sommer, D.W. (1996) 'Capital and risk in property-liability insurance markets', Journal of Banking \& Finance 20(6): 1069-1092.

IAIS (2011) 'Common Framework for the Supervision of Internationally Active Insurance Groups', July 2011, from http://www.iaisweb.org/_temp/ComFrame_Concept_Paper_Final.pdf, accessed 7 May 2012.

The Geneva Association (2010) 'Systemic Risk in Insurance', March 2010, from http://www.genevaassociation .org/PDF/BookandMonographs/Geneva_Association_Systemic_Risk_in_Insurance_Report_March2010.pdf, accessed 7 May 2012.

${ }^{4}$ IAIS (2011). 